\title{
Study on different hook and bait types in the Persian Gulf hand line fishery: optimization and development ${ }^{\star}$
}

\author{
Seyed Yousef Paighambari and Morteza Eighani* \\ Fisheries Department, Gorgan University of Agricultural Sciences and Natural Resources, Gorgan, Iran
}

Received 14 August 2016 / Accepted 26 February 2017

\begin{abstract}
The hand line fishery in the Persian Gulf is considered a sustainable fishing practice. The aims of this study were to estimate catch composition, catch rates, length frequencies, and the percentage of individuals caught below length-at-maturity with two types of hooks, circle and J-style with natural and artificial bait by hand line fishing. Circle and J-style hooks with natural and artificial bait were alternated. Sampling operations were carried out on Qeshm Island, in the North of the Persian Gulf in spring 2015. Catch per unit effort for J-hooks with natural and artificial bait and circle hooks with natural and artificial bait differed significantly $(p<0.05)$; they were $0.9772 \pm 0.25,0.7772 \pm 0.26,0.5688 \pm 0.32$, and $0.4108 \pm 0.23 \mathrm{~kg} / \mathrm{hook} / \mathrm{h}$, respectively. Thus, the highest catch rates were obtained with J-style hooks with natural bait. Kolmogorov-Smirnov tests showed that the length frequency distributions for Lethrinus nebulosus, and Alectis indicus differed significantly between treatments $(p<0.05)$, while no significant differences were found for other species $(p>0.05)$. For most species (except $L$. nebulosus), there was no significant difference between circle and J-style hooks for the proportion of individuals smaller than lengthat-maturity $(p>0.05)$.
\end{abstract}

Keywords: Hook / Bait / Length frequency / Catch rate / Hand line / Persian Gulf

\section{Introduction}

Hand line is one of the most important fishing gears for recreational sectors in the Persian Gulf. In 2016, 1370 small boats landed $12,000 \mathrm{mt}$ caught by handlining around Qeshm Island in the North of the Persian Gulf. Hand line fishing is considered a sustainable fishing practice (Sainsbury, 1996). It is an adaptable fishing method and there are different ways to rig it based on the target species and conditions of fishing. Hand line fishing is used in all seas and oceans, and a substantial part of fish resources is extracted through this method (Bjordal and Løkkeborg, 1996). For example, hand line fishermen land 47,000 mt annually in waters north of Spain (Punzon et al., 2004). Annual landings from hand lines from the Philippines, Vietnam, Thailand, and Cambodia were 24,270, 45,028, 3498, and 15,600 $\mathrm{mt}$, respectively (SEAFDEC, 2001).

Although the hand line fishing method is simple, there are differences in gear structure and operation performance when targeting demersal and large pelagic species. The hand line fishermen from the Iranian waters of the Persian Gulf commonly use two kinds of hooks (circle and J-style) and

\footnotetext{
‡ Supplementary material is only available in electronic form at www.alr-journal.org.

* Corresponding authors: sypaighambari@gau.ac.ir, morteza_eighani@yahoo.com
}

different baits (natural and artificial). J-style and circle hooks (Woll et al., 2001; Mapleston et al., 2008; Curran and Bigelow, 2011; Pacheco et al., 2011; Hannan et al., 2013) and also natural and artificial baits have been compared in several studies (Løkkeborg, 1990; Alós et al., 2009; Carvalho et al., 2015). According to these studies, changes in the hook type and bait could lead to changes in catch rates, catch per unit effort (CPUE), and catch composition.

Currently, there are not enough accurate statistics and information about hand line fishing in the Persian Gulf to set any rules or management limitations that could guarantee sustainable fishing in this area. Monitoring fishing effort, and estimating catch rates and biological parameters of the caught species are a first step in evaluating the sustainability of fishing in the area (MSC, 2009).

The aims of this study were to estimate catch compositions, catch rates, length frequencies, and the percentage of individuals caught below length-at-maturity $\left(L_{\mathrm{m}}\right)$ for two hook types, circle and J-style, with natural and artificial bait in the Persian Gulf hand line fishery.

\section{Materials and methods}

\subsection{Sampling area}

Sampling was carried out off Qeshm Island in spring 2015. Fishing was mainly done in the southwest near the city of 
Qeshm $\left(26^{\circ} 40^{\prime} \mathrm{N}, 56^{\circ} 07^{\prime} \mathrm{E}\right)$, between 1 and 10 nautical miles from the coast. Fishing depth was between 5 and $100 \mathrm{~m}$ and all fishing took place over coastal reefs.

\subsection{Data collection}

For each sampling event, geographic coordinates (using GPS) and time of day were recorded. Caught individuals were identified using valid identification keys from the literature (Dehghaniposhtrodi and Asadi, 1996; Carpenter et al., 1997). All individuals were then counted and weighed. We recorded total length (TL) to the nearest $\mathrm{cm}$. Catch composition was calculated in weight and in numbers. Four treatments were compared: J-style hook with natural bait, J-style hook with artificial bait, circle hook with natural bait, and circle hook with artificial bait. Natural bait was a piece of squid and artificial bait was a plastic lure looking like a squid. The size of the bait was chosen proportionally to hook size.

CPUE was calculated for each treatment as (Anonymous, 2001):

$$
\mathrm{CPUE}=\frac{C}{N D},
$$

where $C$ is the catch in weight $(\mathrm{kg})$ and $N$ is the number of hooks, and $D$ is duration of deployment.

Species diversity was calculated using the Shannon index (Shannon and Weaver, 1949):

$$
H^{\prime}=-\sum P_{i} \ln P_{i}
$$

where $P_{i}$ is the proportion of species $i$ in numbers.

\subsection{Fishing trials and gear}

Handlining is just as its name implies: holding a line in the hand while waiting for a fish to take the bait. If a fish is hooked, it is hauled in by hand. Fishermen raise and lower the line to draw attention to the bait. All operations are done by hand. For the four experimental treatments, a total of 171 deployments were performed. The number of trials with hook sizes of $4 / 0,5$ / $0,7 / 0$, and $8 / 0$ were $42,43,43$, and 43 , respectively; these were equally distributed across $\mathrm{J}$ and circle hooks to avoid possible interaction effects. For this, each fisher was randomly assigned one of the four hook sizes at the start of a fishing trip and thereafter followed a sequential order of hook sizes. Two classes of boats were used: 17 and $20 \mathrm{ft}$. Fishermen carried one hand line set with specific hook and bait types on each trip by each boat. Details of the hand lines are summarized in Table 1.

Fishing trips were carried out daily from dawn until dusk, weather permitting. The duration of each trip varied. Soak time was between 3 and $16 \mathrm{~h}$ and depended on fish availability and weather conditions.

\subsection{Data analysis}

First, the homogeneity of variances and normalization of data were evaluated. We used a randomized complete block design to evaluate the effect of hook sizes on CPUE values. The effect of hook sizes was not significant $(p>0.05)$. An
Table 1. Characteristics of hand lines used for targeting species in the Persian Gulf

\begin{tabular}{ll}
\hline Mainline & Material: monofilament nylon \\
& Dimension: diameter $0.8 \mathrm{~mm}$; length $91.44 \mathrm{~m}$ \\
Snood & Material: wire cable \\
& Dimension: diameter $2 \mathrm{~mm}$; length $0.5 \mathrm{~m}$ \\
Hook & J-style: sizes of $4 / 0,5 / 0,7 / 0$, and $8 / 0$ \\
& Circle Mustad: sizes of $4 / 0,5 / 0,7 / 0$, and $8 / 0$ \\
Bait & Natural: piece of squid \\
Artificial: plastic lure looking like squid \\
Swivel & $\begin{array}{l}\text { Mounting: attached between mainline and } \\
\text { snood to connect the hook to the snood }\end{array}$ \\
& Number: two \\
Sinker & Material: lead \\
& Weight: $\sim 2 \mathrm{~kg}$ \\
\hline
\end{tabular}

analysis of variance was then carried out to evaluate the effect of hook type, bait type and their interaction on CPUE values and diversity indices, and Duncan testing was conducted with a probability level of $5 \%$ to compare means. Mean length by species was compared amongst different treatments with Kruskal-Wallis tests. Using Sturges' formula (Sturges, 1926), individuals were first grouped into length classes, and then length frequency distributions by length class were compared using Kolmogorov-Smirnov tests. Chi-square tests were used to compare the abundance of species and the percentage of individuals caught smaller than the length at first maturation. Analyses of catch composition dissimilarities between treatments were carried out using SIMPER (Clarke, 1993). In order to statistically analyze and store data, Excel, SPSS, and Primer software were used.

\section{Results}

\subsection{Catch composition}

In total, 1306 fish with a total weight of $3886.95 \mathrm{~kg}$ were caught during 171 experimental hand line fishing trips in the Persian Gulf (Table 2). The catch contained 26 fish species belonging to 20 families (Fig. 1). Scomberomorus commerson was the most landed species by weight for J-style hooks with natural and artificial baits. For circle hooks with natural bait Lethrinus nebulosus was the most abundant species in weight, while it was Scomberoides commersonnianus for circle hooks with artificial bait. Two species, Alectis indicus and Sphyraena jello, were taken by all hook and bait types, while two other species, Thunnus tonggol and S. commersonnianus, were caught exclusively with artificial bait (Fig. 1).

Species abundances differed significantly between natural and artificial baits $\left(\chi^{2}\right.$-test, $\left.p<0.05\right)$ and also circle and J-style hooks $\left(\chi^{2}\right.$-test, $\left.p<0.05\right)$. The species in the different treatments (pairwise comparisons) that were responsible for the dissimilarity in catch composition in numbers are shown in Table 3. S. commersonnianus contributed to differences between natural and artificial bait for both hook types, while it was $S$. commerson for hook types. The largest dissimilarity was found between J-style hooks with artificial bait and circle hooks with natural bait. 
Table 2. Main catch data for fishing trips with different treatments.

\begin{tabular}{lllll}
\hline Catch & \multicolumn{3}{c}{ Treatment } \\
\cline { 2 - 5 } & J-hook natural bait & J-hook artificial bait & Circle hook natural bait & Circle hook artificial bait \\
\hline Number of fishing trips & 57 & 39 & 47 & 28 \\
Total fishing time (h) & 415 & 260 & 140 & 115 \\
Total number of individuals & 423 & 303 & 359 & 221 \\
Total weight $(\mathrm{kg})$ & 1985.5 & 1126.82 & 405.3 & 369.33 \\
CPUE $(\mathrm{kg} / \mathrm{hook} / \mathrm{h}) \pm \mathrm{SD}$ & $0.9772 \pm 0.25$ & $0.7772 \pm 0.26$ & $0.5688 \pm 0.32$ & $0.4108 \pm 0.23$ \\
\hline
\end{tabular}
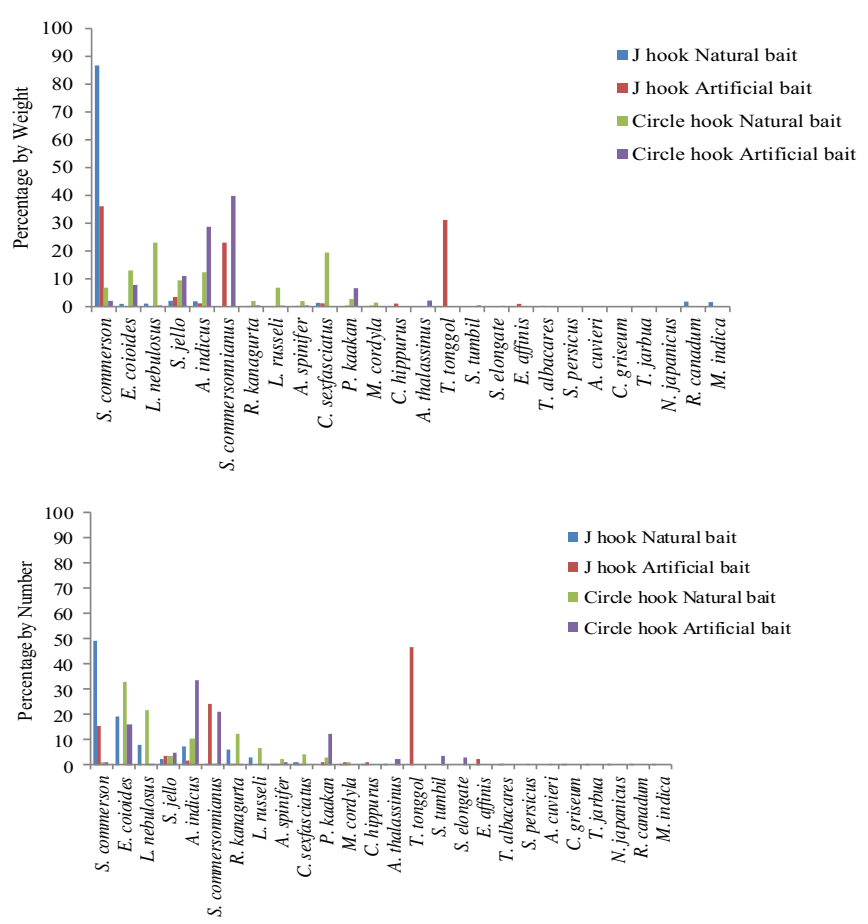

Fig. 1. Catch composition of different treatments by weight and numbers in Qeshm Island, northern Persian Gulf.

\subsection{Number of individuals caught below length-at-maturity}

The percentage of individuals caught below length-atmaturity $\left(L_{\mathrm{m}}\right)$ differed between hook and bait types and ranged from 0 to 100 (Table 4). This proportion could not be determined for some of the species due to the small number of specimens. The results indicated that hand line selectivity was satisfactory for $S$. commersonnianus, S. commerson, and A. indicus for all four treatments. However, for some other species such as T. tonggol and Epinephelus coioides, the majority of the caught individuals were smaller than $L_{\mathrm{m}}$. For L. nebulosus, the percentage of individuals smaller than $L_{\mathrm{m}}$ differed significantly between the circle and J-style hooks $\left(\chi^{2}\right.$-test, $\left.p<0.05\right)$ but for other species, the results were not different for different hook and bait types $\left(\chi^{2}\right.$-test, $\left.p>0.05\right)$.

The length frequency distributions of all species were compared between treatments. Larger individuals of $A$. indicus were caught significantly more by J-hooks with artificial bait $(p<0.05)$. In the case of L. nebulosus, significantly larger individuals were caught by circle hooks with natural bait $(p<0.05)$. But for other species, no significant differences were observed $(p>0.05)$. Based on the results, J-hooks with natural bait caught the largest individuals of $S$. commerson, compared to other treatments.

\subsection{Overall catch rates and diversity}

Hook and bait types had significant effects on overall catch rates for all species combined ( $p<0.05$, Table 5) (Fig. 2). There was no significant interaction between hook type and bait type for overall mean CPUEs $(p>0.05)$. Thus, J-style hooks with natural bait gave the highest catches, while circle hooks with artificial bait gave the lowest. The results were somewhat different for diversity.

The greatest species diversity was obtained using circle hooks with natural bait and the smallest for J-style hooks with artificial bait (Fig. 3, $p<0.05$ ).

\section{Discussion}

Many studies comparing J-style hooks with circle hooks have found significant differences in catch rates (Woll et al., 2001; Prince et al., 2002; Skomal et al., 2002; Cooke et al., 2003; Alós et al., 2009; Afonso et al., 2011; Curran and Bigelow, 2011; Hannan et al., 2013), while in several other studies no differences were found (Mapleston et al., 2008; Carvalho et al., 2015). In the present study, J-style hooks also had higher catch rates and CPUEs, compared to circle hooks. According to the results, the best treatment in terms of catch rates was the J-style hook with natural bait.

The large number of species (26) and diverse catch composition of landed fish revealed that fishers seem to consider a large part of their catch as target species. However, no information on discarded fish was collected in this study. Catch compositions were dominated by $S$. commerson, $S$. commersonnianus, A. indicus, L. nebulosus, and E. coioides, which made up about $85 \%$ of the landed biomass. This catch composition was consistent with published studies from other tropical areas (Low et al., 1985; Ralston et al., 1986; Ali et al., 2004; Mongeon et al., 2013; Zimmerhackel et al., 2015). Handlining is mostly performed in tropical waters and around coral reefs and related to atolls, which have similar species compositions. In our study, catch composition significantly 
Table 3. Pairwise comparison of catch compositions (in numbers) for different hand line hook and bait types (treatments).

\begin{tabular}{lll}
\hline Treatment comparison & Dissimilarity (\%) & Species responsible for dissimilarity \\
\hline J-artificial vs. J-natural & 48 & S. commersonnianus, E. coioides, L. nebulosus, L. russellii \\
J-natural vs. circle-natural & 30 & S. commerson, P. kaakan, A. spinifer, L. nebulosus \\
J-artificial vs. circle-natural & 58 & S. commersonnianus, E. coioides, L. nebulosus, S. commerson \\
J-natural vs. circle-artificial & 53 & S. commerson, S. commersonnianus, $P$. kaakan, L. nebulosus \\
J-artificial vs. circle-artificial & 48 & E. coioides, S. commerson, A. indicus, S. tumbil \\
Circle-natural vs. circle-artificial & 44 & S. commersonnianus, L. nebulosus, R. kanagurta, L. russellii \\
\hline
\end{tabular}

Table 4. Mean length and length range, and percentage of individuals caught below length-at-maturity ( $\left.\% L_{\mathrm{m}}\right)$ in Qeshm Island, northern Persian Gulf. $L_{\mathrm{m}}$ values from Froese and Pauly (2015).

\begin{tabular}{|c|c|c|c|c|c|c|c|c|c|}
\hline Species & $L_{\mathrm{m}}(\mathrm{cm})$ & \multicolumn{2}{|c|}{ J-hook natural bait } & \multicolumn{2}{|c|}{ J-hook artificial bait } & \multicolumn{2}{|c|}{ Circle hook natural bait } & \multicolumn{2}{|c|}{ Circle hook artificial bait } \\
\hline S. jello & 53 & $82 ; 38-119$ & 10 & $81.3 ; 40-110$ & 20 & $67.3 ; 42-112$ & 46 & $80.8 ; 50-110$ & 9 \\
\hline S. commersonnianus & 46 & - & - & $79.25 ; 63-95$ & 0 & - & - & $76.9 ; 50-100$ & 2 \\
\hline E. coioides & 45 & $25.4 ; 15-35$ & 100 & - & - & $30.6 ; 15-65$ & 88 & $38.6 ; 15-55$ & 57 \\
\hline L. russellii & 39 & $27.5 ; 18-65$ & 92 & - & - & $39.6 ; 20-76$ & 60 & - & - \\
\hline P. kaakan & 32 & - & - & - & - & $42 ; 33-50$ & 0 & $40.9 ; 25-60$ & 11 \\
\hline T. tonggol & 73 & - & - & $42.5 ; 25-70$ & 100 & - & - & - & - \\
\hline
\end{tabular}

Table 5. Analysis of variance results for the effects of hook and bait type on total CPUE in Qeshm Island, northern Persian Gulf.

\begin{tabular}{lcrlrl}
\hline & Sum of squares & df & Mean square & $F$ & $p$-value \\
\hline Hook & 0.732 & 1 & 0.732 & 10.177 & $<0.001$ \\
Bait & 0.015 & 1 & 0.015 & 0.211 & 0.045 \\
Hook $\times$ bait & 0.040 & 1 & 0.040 & 0.560 & 0.46 \\
Error & 2.303 & 32 & & & \\
Total & 18.655 & 35 & & & \\
\hline
\end{tabular}

differed between circle and J-style hooks, and also between natural and artificial baits. Rules specifying permitted bait types have been used as a management tool leading to differences in catch rates, catch composition and CPUE (Løkkeborg and Bjordal, 1992; Broadhurst and Hazin, 2001; Arlinghaus et al., 2008; Alós et al., 2009). The type of bait is an effective factor for influencing species selectivity in hand line fishing because nutritional attractions and stimulants are species-specific (Løkkeborg et al., 2014). In this study, it was observed that some of the species, such as $S$. commersonnianus, were caught exclusively with artificial bait and some other species, such as L. nebulosus, were caught mostly with natural bait.

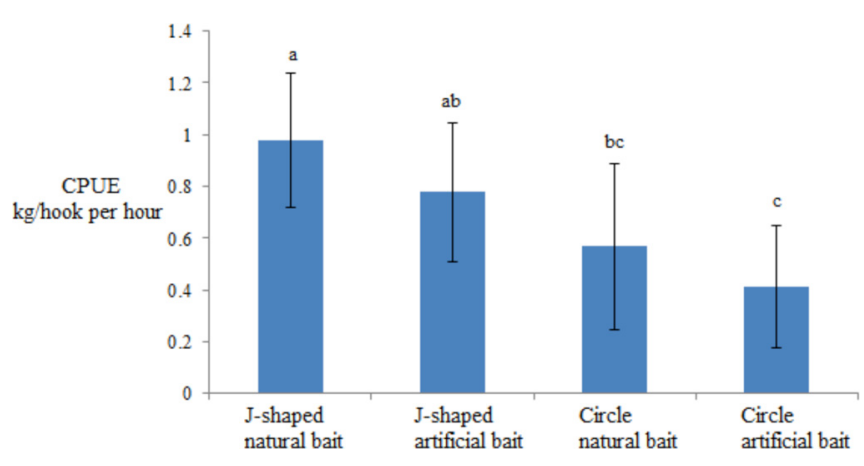

Fig. 2. Comparison between mean CPUEs \pm SD for four treatments ( $\mathrm{J}$ or circle hooks and natural or artificial bait) from experiments carried out in Qeshm Island, northern Persian Gulf. Letters represent pairwise significant differences between treatments. For example, ' $a$ ' means J-hooks with artificial bait were significantly different only with circle hooks with artificial bait.

\subsection{Length frequency and length-at-maturity}

Length frequency distributions did not differ between treatments for most species. Erzini et al. (1997) also found that the type of the bait did not have a significant effect on the length frequency distribution of the caught species. However, in the case of $S$. commersonnianus, artificial bait attracted more individuals. In most fisheries in which small-sized individuals 


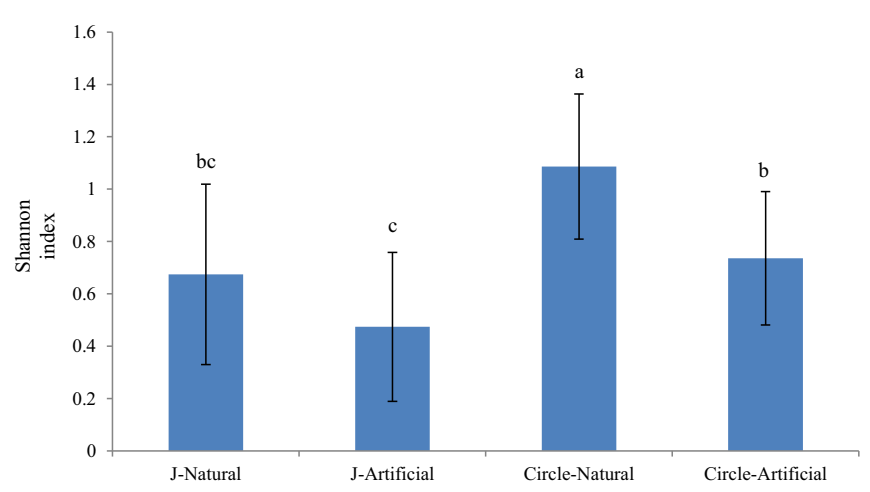

Fig. 3. Comparison of mean Shannon species diversity indices $( \pm \mathrm{SD})$ amongst treatments ( $\mathrm{J}$ or circle hook and natural or artificial bait) for experiments carried out in Qeshm Island, northern Persian Gulf. Letters represent pairwise significant differences between treatments.

are caught, it is preferable to use more natural baits. In fact, smallsized species will not bite on artificial baits (Alós et al., 2009).

The mean length of L. nebulosus, E. coioides, A. indicus, $S$. commersonnianus, Lutjanus russellii, and Pomadasys kaakan caught by pots in Saudi Arabian waters were 32, 35, 32, 46, 35, and $30 \mathrm{~cm}$, respectively (Tharwat and Al-Gaber, 2006). Paighambari et al. (2014) reported that in Hormozgan's waters, most species in the pound net fishery were below minimum landing size. The mean lengths of $E$. coioides, $A$. indicus, $L$. russellii, P. kaakan, S. jello, and S. commerson caught by trawl in Hormozgan waters were $31,15,24,15,30$, and $39 \mathrm{~cm}$, respectively (Eighani and Paighambari, 2013). Erzini et al. (1997), comparing the length frequency of fish caught by monofilament gillnet with those caught with hooks, observed that larger fish were caught with hooks and that fishing with hook reduced the number of immature and undersized individuals significantly. The present results demonstrated significant differences between the size compositions of catches taken by hand line and other fishing gears. The hand line, however, caught fewer individuals that were smaller than length-at-maturity.

In recent years, fishermen have raised concern about unsustainable exploitation of highly vulnerable species by hand line fisheries. E. coioides and T. tonggol are listed as threatened species by the International Union for Conservation of Nature Red List (IUCN, 2016). The results of this study showed that compared to other species, for $E$. coioides and $T$. tonggol, a larger proportion of individuals were below lengthat-maturity $\left(L_{\mathrm{m}}\right)$. In multispecies fisheries catching a diverse range of species more than focusing on overall selectivity, it is important to decrease the exploitation of individuals below $L_{\mathrm{m} 50}$, as well as endangered species (Gillett, 2011). The simplest and cheapest management tool for reducing catching small individuals is to increase the size of hooks and the bait.

The impact of fishing on elasmobranch (sharks and rays) and sea turtle stocks around the world is currently the focus of considerable international concern. In this study, no elasmobranches or turtles were caught although they occur in the study area. To select the most suitable type of hook and bait for the hand line fishery, in addition to catch rates, other ecological factors such as bycatch mortality and survival rates should be considered. For example, circle hooks have significantly lower mortality rates than J-hooks (Domeier et al., 2003; Horodysky and Graves, 2005; Afonso et al., 2011). Further studies will be required to compare bycatch mortality between circle and Jhooks in the Persian Gulf hand line fishery.

Catch rates, catch composition and length frequency distributions are affected by type and size of the hook (Anon, 1983; Erzini et al., 1999), catch strategy (Bjordal and Løkkeborg, 1996), type and size of bait (Moreno et al., 1992; Bjordal and Løkkeborg, 1996), and the use of various swivels and buoys. Therefore, each of these variables needs to be evaluated separately and monitored in the fishery.

\section{Conclusion}

The hand line method is performed in Qeshm Island, northern Persian Gulf all year round. Most of the inhabitants of this coastal region make a living through this type of fishing. We tried to optimize the hand line method by comparing two hook types and two bait types. The results showed that J-style hooks with natural bait had the highest catch rates and CPUEs. The commercially most important fish species in the Persian Gulf hand line fishery is $S$. commerson which is caught mostly with J-hooks with natural bait. Length frequency distributions and the percentage of individuals below the length-atmaturity $\left(L_{\mathrm{m}}\right)$ showed that the hand line method caught bigger individuals compared to pots (Tharwat and Al-Gaber, 2006), pound nets (Paighambari et al., 2014) and trawls (Eighani and Paighambari, 2013). However, for E. coioides and T. tonggol for which a large percentage of individuals was below $L_{\mathrm{m}}$, it is proposed that an increase in hook and bait size should be studied. Once this issue is resolved, the development of hook fishing could be valuable both for the environment and for the fishermen in the region.

\section{Supplementary Material}

Supplementary file supplied by authors. The Supplementary Material is available at https://www.alr-journal.org/ $10.1051 / \mathrm{alr} / 2017007 / \mathrm{olm}$.

\section{References}

Afonso AS, Hazin FHV, Carvalho F, et al. 2011. Fishing gear modifications to reduce elasmobranch mortality in pelagic and bottom longline fisheries off Northeastern Brazil. Fish Res 108: 336-343.

Ali A, Mahyam I, Razak S, Ibrahim J. 2004. A guide to make and set durable artificial reef fish aggregating devices (ARFADs) for coastal areas. Malaysia: Asian Fisheries Development Center, MFRDMD/SP/6, $43 \mathrm{pp}$

Alós J, Arlinghaus R, Palmer M, March D, Álvarez I. 2009. The influence of type of natural bait on fish catches and hooking location in a mixed-species marine recreational fishery, with implications for management. Fish Res 97: 270-277.

Anon A. 1983. Circle hooks outfish traditional halibut hooks. Mar Fish Rev 45: 10-12.

Anonymous. 2001. Working Group on the assessment of Mackerel, Horse Mackerel, Sardine, and Anchovy. ICES CM 2001/ACFM:06.

Arlinghaus R, Klefoth T, Kobler A, Cooke SJ. 2008. Size selectivity, injury, handling time, and determinants of initial hooking mortality in recreational angling for northern pike: the influence of type and size of bait. N Am J Fish Manag 28: 123-134.

Bjordal A, Løkkeborg S. 1996. Longlining. Oxford: Fishing News Books, p. 156. 
Broadhurst MK, Hazin FHV. 2001. Influences of type and orientation of bait on catches of swordfish (Xiphias gladius) and other species in an artisanal subsurface longline fishery off northeastern Brazil. Fish Res 53: 169-179.

Carpenter KE, Krupp F, Jones DA, Zajonz U. 1997. Living marine resources of Kuwait, Eastern Saudi Arabia, Bahrain, Qatar and UAE. FAO species identification field guide for fishery purposes. Rome, Italy: FAO Publication, pp. 1-293.

Carvalho JF, Coelho R, Santos M, Amorim S. 2015. Effects of hook and bait in a tropical northeast Atlantic pelagic longline fishery: part II - target, bycatch and discard fishes. Fish Res 164: 360-369.

Clarke KR. 1993. Non-parametric multivariate analyses of changes in community structure. Aust J Ecol 18: 117-143.

Cooke SJ, Suski CD, Siepker MJ, Ostrand KG. 2003. Injury rates, hooking efficiency and mortality potential of largemouth bass (Micropterus salmoides) captured on circle hooks and octopus hooks. Fish Res 61: 135-144.

Curran D, Bigelow K. 2011. Effects of circle hooks on pelagic catches in the Hawaii-based tuna longline fishery. Fish Res 109: 265-275.

Dehghaniposhtrodi R, Asadi H. 1996. Atlas of the Persian Gulf \& the Sea of Oman fishes. Tehran, Iran: Publication of Iranian Fisheries Organization, 226 pp. (in Persian).

Domeier ML, Dewar H, Nasby-Lucas N. 2003. Mortality of striped marlin (Tetrapturus audax) caught with recreational tackle. Mar Freshw Res 54: 435-445.

Eighani M, Paighambari SY. 2013. Shrimp, bycatch and discard composition of small-scale shrimp trawlers in the Hormuzgan coasts, Iran, in Persian Gulf. Philipp Agric Sci 96: 314-319.

Erzini K, Gonçalves JMS, Bentes L, Lino PJ, Ribeiro J. 1999. Catch composition, catch rates and size selectivity of three long-line methods in the Algarve (southern Portugal). Boletin 15 (1-4): 313-323.

Erzini K, Gonçalves JMS, Bentes L, Lino PG, Ribeiro J. 1997. Longline selectivity and biology of "red" sea breams (Sparidae). Ref. 94/059. Final Report. European Commission, DG XIV/C/1. Faro: Universidade do Algarve, UCTRA, 100 pp. + annexes.

Froese R, Pauly D, eds. 2015. FishBase. World Wide Web Electronic Publication. www.fishbase.org, version (10/2015).

Gillett R. 2011. Bycatch in small-scale tune fisheries: a global study. Technical paper No. 560. Rome: Food and Agriculture Organization, $116 \mathrm{pp}$.

Hannan K, Fogg A, Driggers W, Hoffmayer E. 2013. Size selectivity and catch rates of two small coastal shark species caught on circle and J hooks in the northern Gulf of Mexico. Fish Res 147: 145-149.

Horodysky AZ, Graves JE. 2005. Application of pop-up satellite archival tag technology to estimate post release survival of white marlin (Tetrapturus albidus) caught on circle and straight shank ("J") hooks in the western North Atlantic recreational fishery. Fish Bull 103: 84-96.

Løkkeborg S. 1990. Reduced catch of under-sized cod (Gadus morhua) in longlining by using artificial bait. Can J Fish Aquat Sci 47: 1112-1115.

Løkkeborg S, Bjordal A. 1992. Species and size selectivity in longline fishing: a review. Fish Res 13: 311-322.

Løkkeborg S, Siikavuopio SI, Humborstad OB, Utne-Palm A, Ferter K. 2014. Towards more efficient longline fisheries: fish feeding behaviour, bait characteristics and development of alternative baits. Rev Fish Biol Fish 24 (4): 985-1003.
Low RA, Ulrich GF, Baransa CA, Oakleya DA. 1985. Analysis of catch per unit of effort and length composition in the South Carolina Commercial Handline Fishery, 1976-1982. N Am J Fish Manag 5: 340-363.

Mapleston A, Welch D, Begg G, McLennan M, Mayer D, Brown I. 2008. Effect of changes in hook pattern and size on catch rate, hooking location, injury and bleeding for a number of tropical reef fish species. Fish Res 91: 203-211.

Mongeon C, Granek EF, Arauz R. 2013. Hook selectivity in an artisanal spotted rose snapper Lutjanus guttatus fishery on the Nicoya Peninsula, Costa Rica. Mar Coast Fish 5: 270-280.

Moreno S, Pol J, González C. 1992. Selection properties of the baited hooks used in the Cuban long-line fishery of Campeche bank, Gulf of Mexico. Naga ICLARM Q 15: 28-29.

MSC (Marine Stewardship Council). 2009. Net benefits: the first ten years of MSC certified sustainable fisheries. London: MSC. Available from: www.msc.org/documents/fisheriesfactsheets/netbenefits-report/Net-Benefits-report.pdf (November 2012).

Pacheco JC, Kerstetter DW, Hazin FH, et al. 2011. A comparison of circle hook and $\mathrm{J}$ hook performance in a western equatorial Atlantic Ocean pelagic longline fishery. Fish Res 107: 39-45.

Paighambari SY, Raeisi H, Daliri M, et al. 2014. The effect of temporal and spatial variations on catch community of set net in Hormozgan coastal waters. Gorgan University of Agricultural Sciences and Natural Resources. Research Report, 75 pp.

Prince ED, Ortiz M, Venezelos A, Rosenthal DS. 2002. A comparison of circle hook and $\mathrm{J}$ hook performance in recreational catch and release fisheries for billfish. Am Fish Soc Symp 30: 66-79.

Punzon A, Villamar B, Preciado I. 2004. Analysis of the handline fishery targeting mackerel (Scomber scombrus, L.) in the North of Spain. Fish Res 69: 189-204.

Ralston S, Gooding RM, Ludwig G. 1986. An ecological survey and comparison of bottom fish resource assessments (submersible versus handline fishing) at Johnston Atoll. Fish Bull 84 (1): 14 p.

Sainsbury JC. 1996. Commercial fishing methods: an introduction to vessels and gears. Oxford, U.K.: Fishing News Books.

Shannon CE, Weaver W. 1949. The mathematical theory of communication. Urbana: University of Illinois Press, $144 \mathrm{pp}$.

Sturges HA. 1926. The choice of a class interval. J Am Stat Assoc 21: 65-66.

Skomal GB, Chase BC, Prince ED. 2002. A comparison of circle hook and straight hook performance in recreational fisheries for juvenile Atlantic bluefin tuna. Am Fish Soc Symp 30: 57-65.

Southeast Asian Fisheries Development Center. 2001. Fishery statistical bulletin for the South China Sea Area, 2001. Bangkok: SEAFDEC Secretariat, $155 \mathrm{pp}$.

The IUCN Red List of Threatened Species., Version 2016-2. <www. iucnredlist.org $>$. Downloaded on 05 November 2016.

Tharwat A, Al-Gaber R. 2006. Fishery traps (Gargours) in Saudi territorial waters of the Arabian waters. Mar Sci 17: 13-31.

Woll AK, Boje J, Holst R, Gundersen A. 2001. Catch rates and hook and bait selectivity in longline fishery for Greenland halibut (Reinhardtius hippoglossoides, Walbaum) at East Greenland. Fish Res 51: 237-246.

Zimmerhackel J, Schuhbauer C, Usseglio P, Heel LC, Salinas P. 2015. Catch, bycatch and discards of the Galapagos Marine Reserve small-scale handline fishery. Peer J 3: e995.

Cite this article as: Paighambari SY, Eighani M. 2017. Study on different hook and bait types in the Persian Gulf hand line fishery: optimization and development. Aquat. Living Resour. 30: 23 